\title{
Senile EBV-associated B-cell lymphoproliferative disorder
}

\section{尾山卓 ${ }^{1}$, 中村 栄 男 ${ }^{2}$}

\section{はじめに}

本疾患を簡潔に述べるならば，「加齢に伴う免疫力の低 下を背景要因として, Epstein-Barr virus（EBV）陽性 B 細胞の増殖性 (腫瘍性) 病変により特徵づけられる疾患群」 という事になろう。この疾患概念は比較的新しいものであ り ${ }^{1)}$, 現段階では未だ病理医, 臨床医に広く認知されるに は至っていない.しかしながら, 新たな疾患概念としてコ ンセンサスを得る際に必用とされる諸条件，すなわち，「病 因の存在」,「組織学的特徵」,「臨床的特徵」,「独立疾患と した場合の新たな治療戦略の必要性」などを凡そ満たすと 云えるものと我々は考えている.

本項では, $\mathrm{EBV}$ 関連血液疾患の概説, 本疾患認識に至 った背景, 既に公表した結果, 及びその後の新たな知見及 び今後の方向性，について簡述する.

\section{EBV と血液疾患}

Epstein-Barr virus（EBV）は1964年にアフリカのバー キットリンパ腫培養細胞から発見された. その後, 上咽頭 がんや胃がんなどとの関わりも明らかにされ，歴史的に最 も活発に研究がなされてきたヒトがんウイルス human cancer virusであると言える. その明らかな発癌との関連 にも関わらず, EBV は高度に普遍的なウイルスでもある。 EBV は主に唾液を関した母子感染によって伝播されると 考えられる，わが国の 25 歳以上の成人人口においては，ほ ぼ100\%に近い感染率を示すとされる.

\footnotetext{
1愛知県がんセンター薬物療法部

${ }^{1}$ ( T464-8681 愛知県名古屋市千種区鹿子殿 1-1)

2愛知県がんセンター遺伝子病理診断部

Senile EBV-associated B-cell lymphoproliferative disorder

Takashi Oyama ${ }^{1}$, Shigeo Nakamura ${ }^{2}$

${ }^{2}$ Aichi Cancer Center, Department of Pathology \& Molecular Diugnostics

${ }^{1} 1$ - 1 Kanokoden, Chikusa-ku, Nagoya 464-8681, Japan

TEL : 052-762-6111

FAX : 052-764-2923

e-mail : ${ }^{1}$ t-oyama@aichi-cc.jp ${ }^{2}$ snakamur@aichi-cc.jp
}

$\mathrm{EBV}$ と血液リンパ系疾患との関わりは深い. 表 1 に, 主な $\mathrm{EBV}$ 関連血液リンパ系疾患を示す。知られる限りリ ンパ系疾患が主体であり，顆粒球系など他系統 lineage の 血液細胞には余り関与しないようである。通常, EBVは B 細胞に潜伏（latent）感染することから想像されるよう に, 多くの疾患は B 細胞性である。一方, T 細胞や natural killer (NK) 細胞由来のリンパ増殖性疾患にも EBVは 関わりを有する ${ }^{2,3)}$. 幼児期までの $\mathrm{EBV}$ 初感染はほとんど が無症状で終わるが, 少年期以降に拐ける $\mathrm{EBV}$ 初感染 は, 伝染性単核球症 infectious mononucleosis (IM) とし て発症する. 思春期に多く, ときに kissing disease とも 呼ばれる。また, 稀ではあるが $\mathrm{EBV}$ 初感染は, ウイルス 関連血球食食症候群の原因となる ${ }^{4}$. さらに伴性劣性リン パ増殖性疾患 X-linked lymphproliferative disorder P慢 $^{5}$ 性活動性 $\mathrm{EBV}$ 感染症 ${ }^{6}$ などの致死的な病態を呈する場合 もある.また,ごく最近では, IM 発症者における $\mathrm{EBV}$ 陽性ホジキンリンパ腫の発症リスクが非発症者と比較して 有意に高いという興味深い疫学データが確認されだ). EBV とリンパ増殖性疾患 (lymphproliferative disorder; LPD）との関わりは非常に複雑で, 多岐に亘るものであ ると言える.

本項の主題である加齢性 $\mathrm{EBV}$ 関連 B 細胞リンパ増殖異 常症 senile EBV-associated B-cell LPD は, 免疫不全関連 リンパ腫と最も深い関わりがあるものである ${ }^{8}$.

\section{WHO 分類における免疫不全関連リンパ腫 immunodeficiency-associated LPD}

臟器移植，特に難治性血液疾患に対する骨䯣移植が広く 施行されるにつれ，ときに移植後に特異なリンパ増殖性疾 患の発生を見ることが次第に明らかにされた9!.この免疫 不全関連リンパ増殖異常症は, 多くが B 細胞由来であり, 高率に EBV が関連している. 拒絶対策や移植片対宿主病 対策として用いられる cyclosporin A P FK506等の強力な 免疫抑制療法によって, EBV の再活性化が起こることが 原因とされる. 非常に経過が早く致死的なものから, 免疫 抑制剤の減量に伴い自然退縮を示すものまで, 非常に幅の 広い疾患であることが特徴である.

REAL 分類を踏襲する形で2000年に出版された WHO 
表 $1 \mathrm{EBV}$ 関連血液疾患
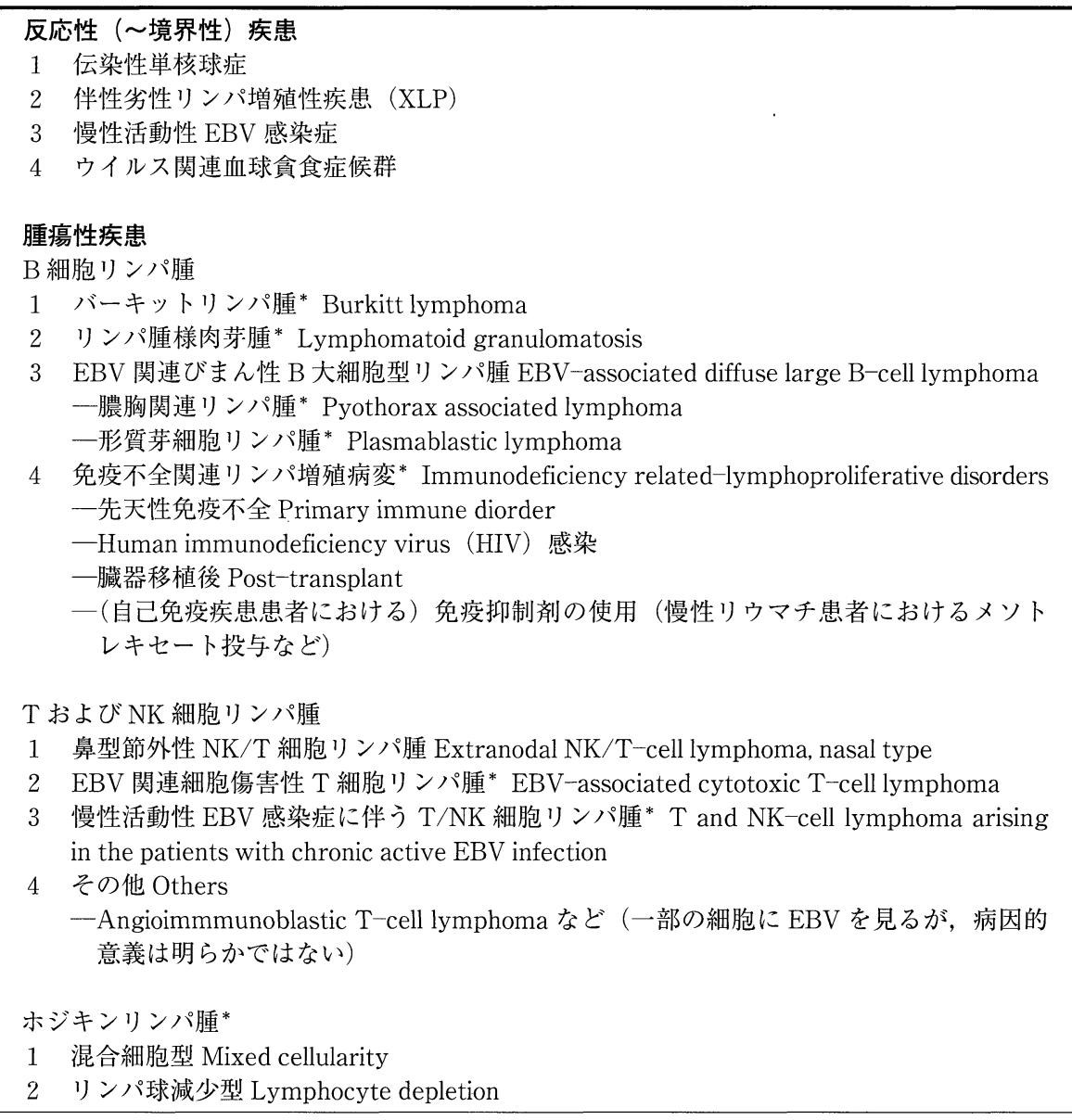

*免疫不全患者で見ることがある.

分類においては，新たに免疫不全関連リンパ腫という項目 が設けられた ${ }^{10)}$.これには以下の 4 つの背景群， 1 . 先天 性免疫不全 primary immune disorder, 2 . human immunodeficiency virus (HIV) 感染, 3 . 臟器移植後 post-transplant，および4. 主に慢性リウマチ患者におけるメソト レキセート methotrexate などの免疫抑制剤投与によるも の, が列記されている.これら個々の背景群には, それぞ れに特徵的な病態・病理所見を持つ LPD がある。例えば， HIV 関連リンパ腫は脳など中枢神経組織に高頻度に浸潤 し, 治療反応性が不良である事が良く知られている だし,いずれの背景群にも関わらず,共通した特徵もある。 炎症性要素に富む多彩な polymorphic 組織像を呈するこ と, 多くは EBV 陽性の B 細胞由来の LPD であること, 節外臟器浸潤が多いこと, などがあげられよう ${ }^{10}$.

加齢性 EBV 関連 B 細胞リンパ増殖異常症

\section{Senile EBV-associated B-cell LPD 認識に至った背景}

本疾患認識の契機は，主に診断困難症例としてコンサル 卜を受けた症例の中に，節外病変であるにも拘わらず一見 ホジキンリンパ腫様の組織像を呈し，腫瘍細胞はB 細胞
性で, かつ EBV 陽性となる一群が存在するという認識に 端を発している，臨床経過上は，急速に進行し予後不良な 症例が多数見受けられた。びまん性 B 大細胞型リンパ腫 diffuse large B-cell lymphoma（DLCL）で EBV が関与す る事は比較的稀なことであり, その臨床病理学的な特異性 とあいまって注目に值する所見と思われた，症例が集積す るにつれ，ほとんどが高齢者であること，節外蔵器を好ん で侵し, 一部症例は LMP 1 のみならず EBNA 2 も陽性で あり免疫不全リンパ腫との関連性が示唆される事, などが 次第に明らかとなった. REAL ${ }^{12)}$ あるいは WHO 分類など 既存のリンパ腫分類に従えば，びまん性 B 大細胞型リン パ腫あるいはホジキンリンパ腫のいずれと診断されるべき かがしばしば問題となる類の病変が含まれる．多くは単に $\mathrm{EBV}$ 陽性びまん性 B 大細胞型リンパ腫と診断されること が多い（そうとしか分類の仕様が無い）訳であるが，次の 問題点が指摘されよう．現在のリンパ腫分類におけるびま 几性 B 大細胞型リンパ腫とは，基本的に多様な疾患群と みなされ，今後更に体系化されるべきというのが多くの血 液病理医，内科医の見解であろう（山口らによる CD 5 positive lymphoma ${ }^{13)}$ ，あるいは遺伝子発現パターンによる 
表 2 患者背景

\begin{tabular}{|c|c|c|c|c|c|c|c|}
\hline 症例番号 & 年齢/性別 & IPI & 組織分類 & 治療 & 治療反応 & 追跡期間 (月) & 転帰 \\
\hline 1 & $86 / \mathrm{F}$ & $\mathrm{HI}$ & LCL & VP & PD & 0.5 & 原病死 \\
\hline 2 & $60 / \mathrm{M}$ & LI & LCL & $\mathrm{CHOP}$ & PD & 6 & 原病死 \\
\hline 3 & $83 / \mathrm{M}$ & LI & LCL & CHOP & PD & 3 & 原病死 \\
\hline 4 & $60 / \mathrm{F}$ & $\mathrm{L}$ & LCL & CHOP & $\mathrm{CR}$ & $43+$ & 無病生存 \\
\hline 5 & $76 / \mathrm{M}$ & $\mathrm{H}$ & LCL & Operation & $\mathrm{PD}$ & 9 & 原病死 \\
\hline 6 & $69 / \mathrm{M}$ & $\mathrm{H}$ & LCL & THP-COP & $\mathrm{CR}$ & 8 & 原病死 \\
\hline 7 & $64 / \mathrm{F}$ & $\mathrm{L}$ & LCL & CHOP & $\mathrm{PD}$ & 6 & 原病死 \\
\hline 8 & $75 / \mathrm{F}$ & LI & LCL & $\mathrm{CHOP} / \mathrm{RT}$ & $\mathrm{PD}$ & 5 & 原病死 \\
\hline 9 & $70 / \mathrm{M}$ & $\mathrm{L}$ & LCL & CHOP & $\mathrm{CR}$ & $2+$ & 無病生存 \\
\hline 10 & $79 / \mathrm{M}$ & LI & PLPD & RT & $\mathrm{CR}$ & $17+$ & 再発, 2 nd CR \\
\hline 11 & $82 / \mathrm{M}$ & $\mathrm{L}$ & PLPD & THP-COP & $\mathrm{CR}$ & $23+$ & 無病生存 \\
\hline 12 & $88 / \mathrm{M}$ & LI & PLPD & THP-COP & CR & $22+$ & 無病生存 \\
\hline 13 & $79 / \mathrm{F}$ & $\mathrm{L}$ & PLPD & none & 自然退縮 & $20+$ & 無病生存 \\
\hline 14 & $73 / \mathrm{F}$ & LI & PLPD & $\mathrm{CHOP}$ & CR & $15+$ & 有病生存 \\
\hline 15 & $83 / \mathrm{M}$ & LI & PLPD & CHOP & CR & 5 & 他病死 \\
\hline 16 & $68 / \mathrm{M}$ & $\mathrm{H}$ & PLPD & PMACECBOM & $\mathrm{CR}$ & $6+$ & 無病生存 \\
\hline 17 & $85 / \mathrm{M}$ & $\mathrm{HI}$ & PLPD & PSL + VP16 & PD & 1 & 原病死 \\
\hline 18 & $78 / \mathrm{M}$ & $\mathrm{HI}$ & PLPD & THP-COP & $\mathrm{CR}$ & $8+$ & 有病生存 \\
\hline 19 & $78 / \mathrm{F}$ & $\mathrm{HI}$ & PLPD & CHOP & $\mathrm{CR}$ & $9+$ & 無病生存 \\
\hline 20 & $71 / \mathrm{F}$ & $\mathrm{HI}$ & PLPD & CHOP & CR & $8+$ & 無病生存 \\
\hline 21 & $69 / \mathrm{F}$ & $\mathrm{L}$ & PLPD & Operation & $\mathrm{CR}$ & $47+$ & 無病生存 \\
\hline 22 & $63 / \mathrm{F}$ & $\mathrm{H}$ & PLPD & CHOP & $\mathrm{CR}$ & $21+$ & 再発, 2 nd CR \\
\hline
\end{tabular}

略語：IPI, intenational prognostic index ; L, low ; LI, low-intermediate ; HI, high-intermediate ; H, high LCL, large cell lymphoma; PLPD, polymorphic lymphoproliferative disorder

VP, vincristine and prednisone ; RT, radioptherapy ; CHOP, cyclophosphamide, doxorubicin, vincristine, and prednisone

THP-COP, cyclophosphamide, pirarubicin, vincristine, and prednisone

PMACECBOM, prednisone, cyclophosphamide, doxorubicin, etoposide, cytocine arabinocide, bleomycin, vincristine, and methotrexate

分類 ${ }^{14)}$ ，など)。そのような立場から，高齢者に発生する 特異な $\mathrm{EBV}$ 陽性 $\mathrm{B}$ 細胞リンパ増殖異常症も単なる $\mathrm{EBV}$ 陽性びまん性 B 大細胞型リンパ腫との診断を越えて，加 齢に伴う免疫機能の低下を背景として病態・病理所見に一 定の共通項と連続性を有する新たな一つの臨床病理学的疾 患単位として認識すべきというのが我々の主張である，今 後に予想される，わが国における人口分布の急速な高齢化 に鑑みて，至近の問題と思われる．以下に22症例を対象に 行なった解析の結果を示す.

\section{対象症例}

愛知県がんセンターのリンパ腫ファイル（コンサルテー ションケースを含む）から後方視的に抽出したびまん性 B 大細胞型リンパ腫を主体とする大型 B 細胞増殖病変 403 例 から, in situ hybridization により EBV-encoded small RNA

（EBER）陽性となる症例を抽出した，既によく知られた $\mathrm{EBV}$ 関連疾患である膿胸関連リンパ腫 ${ }^{15}$ や HIV 関連リン パ腫などの明らかな免疫不全の背景要因を有さない22例の $\mathrm{EBV}$ 陽性大型 $\mathrm{B}$ 細胞リンパ増殖異常症が最終的に同定さ れた。これら症例に対し, 組織像, 病態, 治療反応性など を調查・解析した。

\section{患者背景}

表 2 に主な患者背景因子を示す，性差は特になく，男女

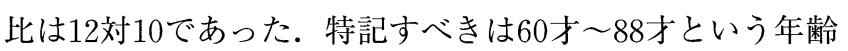
分布であり, 中央值は76歳であった. 全例において免疫不 全を示唆する既往歴，生活歴などは認めず，また検査した 限りにおいて，HTLV1及びHIV は除性であった。また 自己免疫疾患の既往も認めなかった。

$50 \%$ の症例で発熱, 寝汗, 体重減少 (B 症状)を認めた.

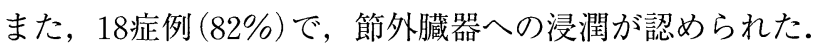
その部位に特徵があるといえ, 皮膚 ( 5 症例), 肺 (4 症 例）など，通常のびまん性 B 大細胞型リンパ腫としては 比較的稀な部位への浸潤傾向が認められた. 浸潤部位から 見る限り, Jaffe らによって提唱されたリンパ腫様肉芽腫 症 lymphomatoid granulomatosis $(\mathrm{EBV}+)^{16)}$ との関連が示 唆された.

\section{病理所見}

通常のびまん性 B 大細胞型リンパ腫と比べて，以下の 特徵が列記される。しばしば強い炎症性背景, すなわち小 リンパ球, 形質細胞, 組織球などの浸潤 (polymorphous appearance）を伴い，ときに炎症性（良性）病変との鑑 


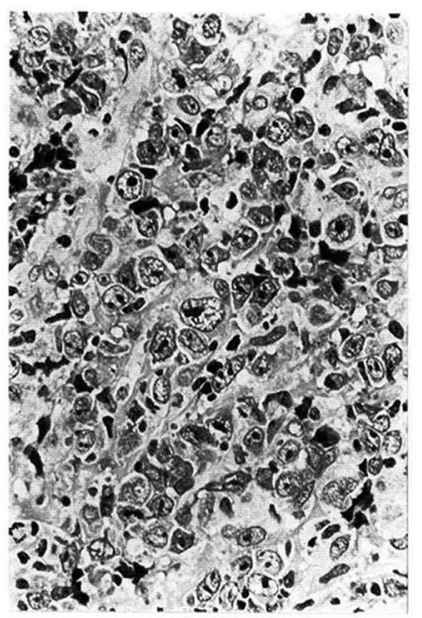

図 1 加齢性 $\mathrm{EBV}$ 関連 B 細胞リンパ増殖異常症 Senile EBVassociated B-cell LPD, large cell lymphoma type の組織 像

大型異型細胞の增殖を認める.

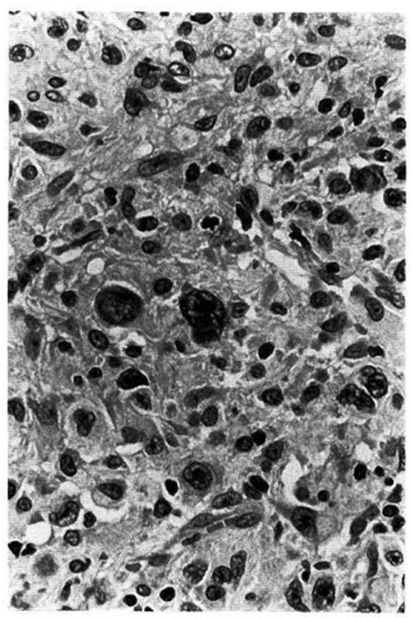

図 2 加齢性 EBV 関連 B 細胞リンパ増殖異常症 Senile EBVassociated B-cell LPD, polymorphic LPD type $の$ 組織像 多彩な細胞構成を示す. 中央には Reed-Sternberg Cell 様の 巨細胞を認める。

別が問題となる。 また，17症例で, 病変内に広範囲かつ高 度の壊死部分が観察された. 血管中心性増殖，血管破壊性 増殖もときに見られる特異的な所見であった。大型異型り ンパ球系細胞は B 細胞性であるが, 背景の浸潤小型リン パ球形細胞はむしろ $\mathrm{T}$ 細胞優位であった。また，ホジキ ンリンパ腫で観察される Reed-Sternberg 細胞様の巨細 胞, 核小体の目立つ大型細胞が15例で認められた. ホジキ ンリンパ腫との鑑別は, それら大型細胞の多くが B 細胞 マーカー（CD20，CD79a など）陽性である点に尽きる。

22 症例の病理組織学的所見の検討から，大きく 2 群に大 別された. すなわち 9 症例は, 大型異型細胞 (腫瘍細胞) が密に増殖する部分, すなわちびまん性 B 大細胞型リン

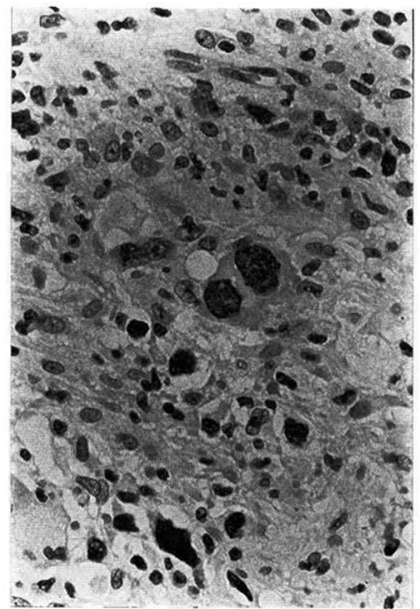

図 3 EBNA 2

核に明らかな陽性シグナルを認める。

パ腫との認識が比較的容易なものあった（図 1 )。この一 群は，大細胞リンパ腫亜型 large cell lymphoma subtype と分類された．他の13症例では，異型大型細胞の集簇が認 められず背景の反応性要素が優位であり反応性病変あるい はホジキンリンパ腫との異同鑑別が問題となる病変であっ た。これらは, リンパ増殖異常症亜型 polymorphic LPD （PLPD）subtype に分類された（図 2 ).

\section{免疫染色と EBV 関連タンパク発現パターン}

本解析の対象症例の定義からも明らかなように，全症例 でEBER は陽性であった。また全症例において腫瘍細胞 は B 細胞マーカー (CD20，CD79a）陽性であった。CD30 の発現が半数の症例で認められたが, CD15は全例で陰性 であった，背景の T 細胞は，CD 8 陽性細胞が，しばしば 優位であった。

LMP 1 は全症例で陽性であり，特筆すべきはEBNA 2 陽性例が 7 症例あったことである（図 3 )。従来，EBNA 2 の発現, すなわち latency 3 パターンは, lymphoblastoid cell line や高度の免疫抑制状態 (AIDS や骨髄移植後) での み認められる所見とされてきた．加齢性 EBV 関連 B 細胞 リンパ増殖異常症の約三分の一にEBNA 2 を認めたとい う事は, 背景に存在するであろう免疫力の低下という我々 の仮説を強く支持する所見と考えられよう。また治療戦略 として, 細胞療法や免疫療法等の可能性を示唆する所見で もあろう ${ }^{6}$.

\section{PCR 法による免疫グロブリン重鎖遺伝子の解析}

加齢性 $\mathrm{EBV}$ 関連 $\mathrm{B}$ 細胞リンパ増殖異常症 22 症例のう ち，パラフィンブロック等から遺伝子が利用可能であった 12症例について PCRによる免疫グロブリン重鎖異伝子 


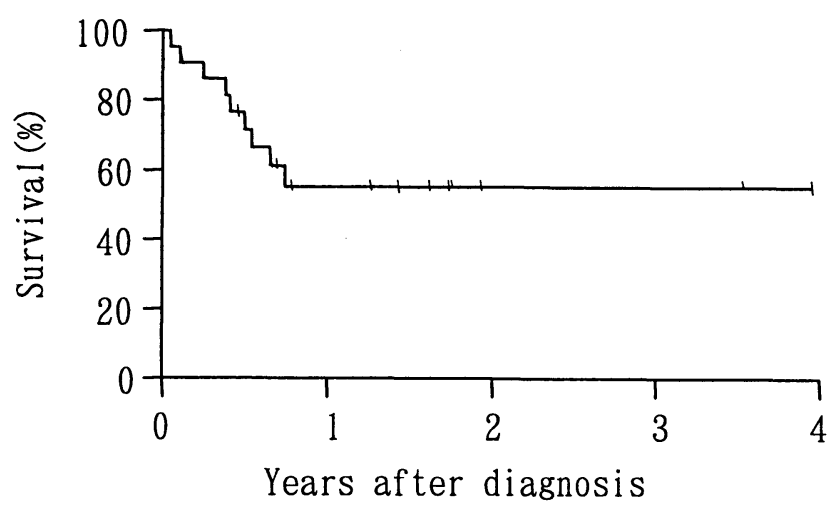

図 4 22症例の Overall survival

(IgH) のクリナリティー解析を行なった ${ }^{17)} .9$ 症例でモ ノクロナリィーが証明された。組織覀型別では，大細胞リ ンパ腫亜型 5 症例中 4 例がモノクロナーナルな増殖を呈し た. 同様にリンパ増殖異常症亜型 7 例中 5 例にクロナイテ イーが証明された。移植後リンパ増殖性疾患においては, 同一患者の複数の検体から異なる再構成バンドが検出され ること等が知られており，PCR 結果の解釈には慎重な態 度が必要とされる。今回の解析からは組織学的な二亜型間 に明らかな差は認められず，当面，全体を一連の腫瘍性疾 患として取り扱う（化学療法の対象とする）ことの一つの 根拠とはなろう.

\section{治療反応, 転帰}

22例中18症例が多剂併用化学療法を施された。他は，手 術のみが 2 例, 放射線治療のみ 1 例, 経過観察 1 例であっ た. 化学療法の内容は, 16例で CHOP に代表されるアン スラサイクリン系薬剤を含んでおり，高齞患者であっても 積極的な化学療法が選択されたと言える.

全症例の生存曲線を図 4 に示す。早期死亡を示す一群 と, 比較的予後良好群との 2 つのグループが認められた. この結果を受け，前述した組織学的な亜型分別による 2 群 の生存曲線の比較を図 5 に示す.今回の検索の範囲内で は, 組織亜型と大細胞リンパ腫亜型において，完全寛解 complete remission（CR）を得られた症例は 9 例中 3 例の みであったのに対し，リンパ増殖異常症亜型では13例中11 例がCRであった。この 2 群間において，年歯，国際予後 指標 (IPI), 及び治療法には有意な差は認められなかった.

\section{終わりに 一新たな知見と今後の展望一}

以上 22 症例の解析によって, 加齢性 $\mathrm{EBV}$ 関連 B 細胞リ ンパ増殖異常症という疾患の輪郭は示し得たものと自負し ている.しかしながら, 少数例からの後方視的解析であり, 今後の更なる症例の積み重ねによる解析が必用なことは言 うまでも無い.

現在, 多数施設の先生方のご好意により症例が集積され

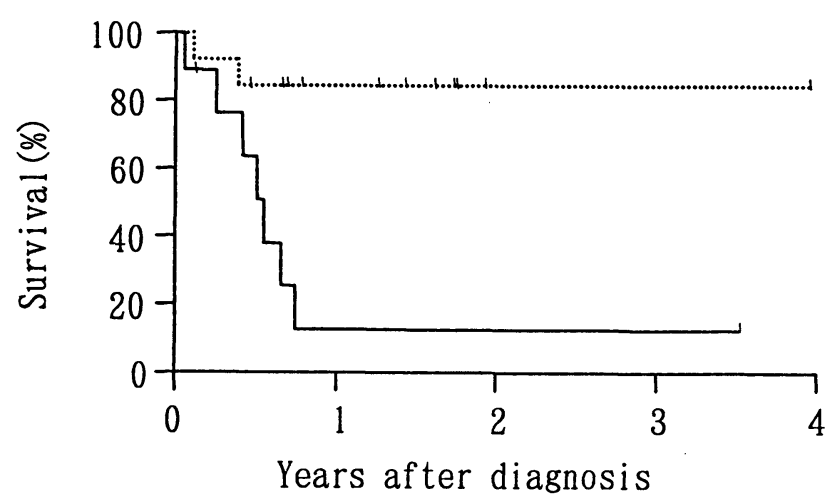

図 5 組織学的分類による Overall survival large cell lymphoma case (実線) の生存は, polymorphic LPD case（破線）との比較で，有意に不良である.（p=0.003）

つつある。組織型による生存率の差は有意ではあるが小さ くなる傾向が見られ, 組織型に関わらず Senile EBV-associated B-cell LPD を予後不良な一つの疾患と捉えるべき ものと思われる。

また後方視的研究には症例選択などにおいて多大な偏り が避けられない.今後は症例を前方視的に登録するシステ ムの構築が必要と思われる。

\section{参考文献}

1 ) Oyama, T., Ichimura, K., Suzuki, R. et al. : Senile EBV + B-cell lymphoproliferative disorders: a clinicopathologic study of 22 patients. Am J Surg Pathol 2003, $27: 16-26$.

2) Kagami, Y., Suzuki, R., Taji, H. et al. : Nodal cytotoxic lymphoma. A clinicopathologic study of 66 patients. Am J Surg Pathol 1999, 23 : 1184-1200.

3 ) Ishii Y, Yamanaka N, Ogawa K, et al. : Nasal T-cell lymphoma as a type of so- $^{-}$called "lethal midline granuloma”. Cancer 1982, 50:2336-2344.

4 ）河 敬世.：血球貪食症候群Hemophagocytic Syndrome. 日本網内系学会1997, 37：9-17.

5 ) Sayos J, Wu C, Morra M, et al. : The X-linked lymphoproliferative-disease gene product SAP regulates signals induced through the co-receptor SLAM. Nature 1998, 395:462-469.

6 ) Kuzushima K, Yamamoto M, Kimura H, et al. : Establishment of anti-Epstein-Barr virus (EBV) cellular immunity by adoptive transfer of virus-specific cytotoxic T lymphocytes from an HLA-matched sibling to a patient with severe chronic active EBV infection. Clin Exp Immunol 1996, 103 : 192-198.

7 ) Hjalgrim H, Askling J, Rostgaard K, et al. : Characteristics of Hodgkin's lymphoma after infectious mononucleosis. N Engl J Med 2003, 349 : 1324-1332.

8 ) Knowles DM. : Immunodeficiency-associated lymphoproliferative disorders. Mod Pathol 1999, $12: 200$ 217.

9 ) Knowles DM, Cesarman E, Chadburn A, et al. : Correlative morphologic and molecular genetic analysis 
demonstrates three distinct categories of posttransplantation lymphoproliferative disorders. Blood 1995, $85: 552-565$.

10) Jaffe, E. S., Karris, N. L., Stein, H. et al. : World Health Organization Classification of Tumours. Pathology \& Genetics. Tumours of Hematopoietic and Lymphoid Tissues, IARC Press, Lyon, 2001

11) Slobod KS, Taylor GH, Sandlund JT, et al. : EpsteinBarr virus-targeted therapy for AIDS-related primary lymphoma of the central nervous system. Lancet $2000,356: 1493-1494$.

12) Harris NL, Jaffe ES, Stein H, et al. : A revised European-American classification of lymphoid neoplasms : a proposal from the International Lymphoma Study Group. Blood 1994, 84 : 1361-1392.

13) Yamaguchi $M$, Seto $M$, Okamoto $M$, et al. : De novo CD 5 + diffuse large B-cell lymphoma : a clinicopathologic study of 109 patients. Blood 2002, 99:815821.
14) Rosenwald A, Wright G, Chan WC, et al. : The use of molecular profiling to predict survival after chemotherapy for diffuse large- $\mathrm{B}-$ cell lymphoma. N Engl J Med 2002, 346 : 1937-1947.

15) Iuchi, K., Aozasa, K., Yamamoto, S. et al. : Non-Hodgkin's lymphoma of the pleural cavity developing from long-standing pyothorax. Summary of clinical and pathological findings in thirty-seven cases. Jpn J Clin Oncol 1989, $19: 249-257$.

16) Guinee D Jr, Jaffe E, Kingma D, et al. : Pulmonary lymphomatoid granulomatosis. Evidence for a proliferation of Epstein-Barr virus infected B-lymphocytes with a prominent $\mathrm{T}$-cell component and vasculitis. Am J Surg Pathol 1994, $18: 753-764$.

17) Reed TJ, Reid A, Wallberg K, et al. : Determination of B-cell clonality in paraffin-embedded lymph nodes using the polymerase chain reaction. Diagn Mol Pathol 1993, 2 : 42-49. 